\title{
EFFECT OF SELENIUM AND /OR VITAMIN E ON BOVINE HERPES TYPE 1 INFECTION IN VITRO CULTURED CELLS
}

\author{
UMIMA M. MANSOUR ${ }^{*}$ and HALA A. SALEM ${ }^{* *}$ \\ * Department of Reproductive Biology, Animal Reproduction Research Institute. \\ ** Department of Reproductive Diseases, Animal Reproduction Research Institute.
}

\section{ABSTRACT}

Received at: 29/6/2015

Accepted: 29/7/2015
Bovine herpes virus type 1 (BHV-1) still the causes of great economic lossesin the livestock industry and trade because there are no available drug that proved to be fully effective against it. In this study, the antioxidant of selenium and/ or the vitamin $\mathrm{E}$ were evaluated as a natural anti-viral drugs. The antiviral activities against Bovine Herpesvirus type 1 (BHV-1) were evaluated by the reduction of the viral cytopathic effect 1nMadin-Darby Bovine Kidney cell line (MDBK) with, GSH (glutathione reduced) and MAD (malondialdehyde) assays. Selenium in concentrations 0.01 and $0.1 \mu \mathrm{M}$ and / or Vit. E in concentrations 50 and $100 \mu \mathrm{M}$ with two concentrations were added at different stages of the viral infection (pre and post treatment). This study concluded that the higher concentration of Selenium and Vit. E $(0.1 \mu \mathrm{M}+100 \mu \mathrm{M}$ respectively) reduced the Cytopathic Effect (CPE) of BHV-1 1n 50\% and increased GSH level as well as decreased MDA level, in pre infection treatment assay.

Key words: Selenium, Vitamin E, Bovine Herpes, In Vitro

\section{INTRODUCTION}

Bovine herpesvirus-1 (BHV-1), also called infectious bovine rhinotracheitis/ infectious pustular vulvovaginitis virus, is a member of the subfamily Alphaherpesvirinae and is one of the most common viral pathogens found in bovine semen (Afshar and Eaglesome., 1990). Reproductive disorders caused by BHV-1 include infectious pustular vulvovaginitis, endometritis, salpingitis, shortened estrus cycles and abortions in susceptible female cattle and balanoposthitis in susceptible bulls (Biswas et al., 2013). In BHV-1 infection of the genital tract of the bull, the virus replicates in the mucosae of the prepuce, penis and distal part of the urethra, and semen is most likely to be contaminated during ejaculation by virus shedding from infected mucosae (Chowdhury, 2010). BHV-1 causes economically important genital, respiratory and neurological diseases in cattle populations world-wide. Infected animals may be immunosuppressed and thus be more susceptible to secondary bacterial infections. BHV-1 infection of the male genital tract can result in mild or severe clinical signs of balanoposthitis or can be clinically unapparent (Vander, 1995). Bulls play an important role in the dissemination of the disease because the virus is excreted in semen both during the acute phase of infection and also following the establishment of latent infection (Smits et al., 2000).

Oxidative stress has been implicated as a possible mechanism leading to selection of more virulent viral genotypes. Selenium and vitamin E deficiency increase viral disease progression with Coxsackie virus in mice (Beck et al., 1994 and Beck et al., 1995). A similar finding was observed when an attenuated strain of influenza A rapidly gained virulence upon passage through selenium deficient mice (Nelson et al., 2001). These results suggest dietary effects on oxidative stress may influence viral disease progression. Selenium status in grazing crops is dependent on incorporation from soil. The Se status of Egyptian soils and plants is generally low and its location in the international field is definitely among low Se countries (Mikko and Hakan, 1992). Vitamin $\mathrm{E}$ is synthesized by plants but not by animals. Grass normally contains adequate levels of vitamin $\mathrm{E}$, Cereals contain moderate levels of vitamin $\mathrm{E}$, but the maturity and storage of feed materials affect their vitamin E content (Bradley et al., 1986). However, it is known that animal requirements depend on age, physiological stage and species (Villar et al., 2002). Adult cows with a selenium/vitamin E deficiency may be more susceptible to diseases (Kommisrud 
et al., 2005) and (Allison and Laven, 2000). It has been reported that white cell function from cows with higher blood selenium concentrations have a better killing ability and therefore may be better able to resist diseases (Cebra et al., 2003). Also Taylor et al. (1997) strongly suspect that various herpes viruses will prove responsive to selenium therapy that selenium is playing a role in cell signaling and attachment. Furthermore, Se may have not only preventive, but also therapeutic in the treatment of HIV infections (Taylor et al., 1994). One function of $\mathrm{Se}$ is as a cofactor for the antioxidant enzyme, glutathione peroxidase. A deficiency in Se leads to decreased glutathione peroxidase activity. Malondialdehyde (MDA) released from oxidative damage (Rayman, 2000). The increased pathology and altered viral genome found in the Coxsackie virus infected Se-deficient mice may be due to a reduction in glutathione peroxidase activity (Beck et al., 1995) reduced glutathione (GSH) functions as an antioxidant in several ways a substrate for glutathione peroxidase $\left(\mathrm{GSH}-\mathrm{P}_{\mathrm{X}}\right)$ (Moron et al., 1979). Despite evidence supporting a beneficial effect on cow health with additional selenium/vitamin E supplementation (LeBlanc et al., 2002; ADAS, 2004; Sivertsen et al., 2005), but the effect of those antioxidants on BHV-1 is not studied yet. Therefore there is a need to contine research to control BHV-1.The present work aimed to study the antiviral effect of selenium (as sodium selenite) or / and Vitamin E on BHV-1 infection in vitro cultured cells in pre and post-infection.

\section{MATERIALS and METHOD}

- Cell culture: Continuous cell line of Madin Darby Bovine Kidneycells (MDBK) were supplied by Virology unit, Reproductive Diseases Department, MDBK cells were maintained at $37^{\circ} \mathrm{C}$ with $5 \% \mathrm{CO} 2$ for $24 \mathrm{~h}$ in culture flasks with MEM (Minimum Essential Media). Subcultures every 2-3 days after formation of confluent monolayer was done.

- Virus: BHV-1 was kindly obtained from Virology unit Reprodictive Diseases Department. BHV-1 was grown in MDBK cells which were also used for measurement of viral Infectivity (virus titration) by a dilution method using a 96-well micro titer plate. The infection titer was expressed as 50\% Tissue Culture Infectious Dose (TCID50) calculated by the formula of Reed and Muench., 1938. The infection titer of BHV-1 stock solution was $10^{7}$ TCID50.

Preinfection treatment assay: Confluent monolayer cultures of MDBK cells were grown in 24 wellplates, treated with different concentration of selenium and vitamin $\mathrm{E}$, incubated for $24 \mathrm{~h}$ at $37^{\circ} \mathrm{C}$ and then infected with BHV-1. Results were examined after 3 days of inoculation. Percentages of Cytopathic Effect (CPE) were calculated as following:

\section{$\mathrm{CPE} \%=\frac{\text { Noofwellshaving CPE }}{\text { TotalWo-oninfectedwells }}$}

- Postinfection treatment assay: Confluent monolayer cultures of MDBK cells were grown in 24 wellplates, inoculated by BHV-1, incubated for $24 \mathrm{~h}$ at $37^{\circ} \mathrm{C}$ and then treated with different concentration of selenium and vitamin E. The plates were incubated for 3 days and \% CPE was calculated as mentioned above.

- Preparation of antioxidant treatments:

Sodium selenite and vitamin E (di-alpha -tocopheryl acetate) were purchased from Sigma. Two concentrations of sodium Selenite $(0.01$ and $0.1 \mu \mathrm{M})$ diluted to the final concentration in assay medium (Minimum Essential Media; MEM). To be selenium adequate cells (Saguna, 2008) Two concentrations of vitamin E $(50$ and $100 \mu \mathrm{M})$ were prepared first by dissolving in absolute ethanol then diluted to the final concentration in assay media to be vitamin Eadequate cells (Norimasa et al., 1999). Mixture of selenium and vitamin $\mathrm{E}$ was prepared. Six-well plates were prepared for each concentration of selenium and / or vitamin E. The controls consisted of untreated infected cells for virus control, confluent monolayer cells were infected with the virus at $10^{7} \mathrm{TCID}_{50} / \mathrm{ml}$ of virus (virus control); and treated uninfected cells for Selenium and Vitamin E controls (cell control). MEM without selenium and vitamin $\mathrm{E}$ After 3 days of incubation, the CPE\% was calculated. At the end of the incubation period, cell lysates were obtained by repeated cycles of freezing and thawing in liquid nitrogen. Samples of cells and supernatants were collected and centrifuged at $1500 \mathrm{~g}$ for $10 \mathrm{~min}$ at $4 \mathrm{C}$. $0.5 \mathrm{ml}$ of supernatant medium was collected from the different groups and stored frozen at $-70 \mathrm{c}$ until assayed for GSH and MDA concentration. Glutathione reduced and Malondialhyde were determined using kits according to Beutier et al. (1963) and Satoh (1978) respectively.

\section{Statistical analysis:}

Data from separate groups are expressed as means \pm standard error. The statistical significance of observed differences between means was determined using ANOVA for comparing means of different samples and was defined as $\mathrm{p}>0.05$ according to Snedecor and Cochran (1987).

\section{RESULTS}

Cytotoxicity Effect of Antioxidant Agents, selenium and vitamin E, were applied with different concentrations and two infection protocols (pre, and post infection treatment assays) on the cell culture system. Firstly those antioxidants applied without inoculation of the virus to evaluate the toxicity effect of the agents. Both agents with different concentrations showed no toxicity on the cells (-ve cytotoxicity) for the whole 72 hours (Table 1). 
Assiut Vet. Med. J. Vol. 61 No. 146 July 2015

Table 1: Cytotoxicity Effect of selenium and vitamin E on MDBK cells

\begin{tabular}{lcccc}
\hline Antioxidant & Concentration & $\begin{array}{c}24 \mathrm{hr} \\
\text { Cytotoxicity }\end{array}$ & $\begin{array}{c}48 \mathrm{hr} \\
\text { cytotoxicity }\end{array}$ & 72 hrcytotoxicity \\
\hline Selenium & 0.01 and $0.1 \mu \mathrm{M}$ & -ve & -ve & -ve \\
\hline Vitamin E & 50 and $100 \mu \mathrm{M}$ & -ve & -ve & -ve \\
\hline Selenium+Vit.E & 0.1 and $100 \mu$ Mrespectively & -ve & -ve & -ve \\
\hline
\end{tabular}

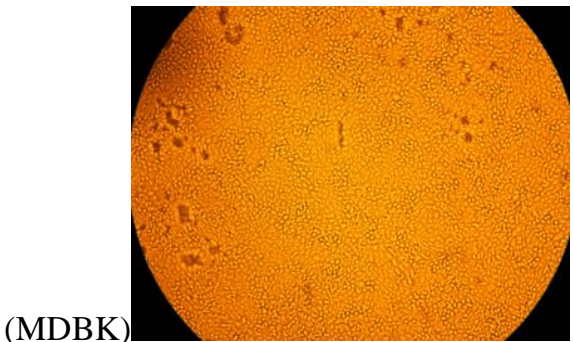

Fig. 1: Complete sheet of cell control culture

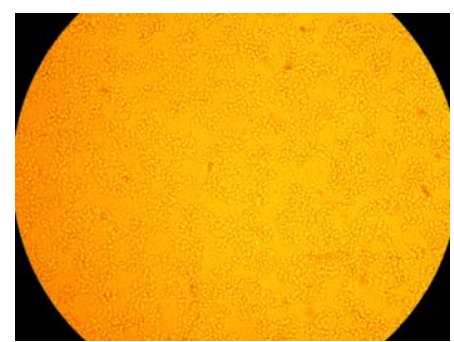

Fig. 2: 50\%Cytopathic effect by the addition of higher con. of selenium +vitamin $\mathrm{E}$ in pre infection protocol.

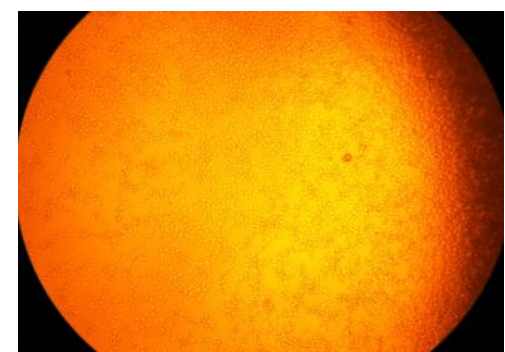

Fig. 3: 66\% cytopathic effect by addition of higher conc. of selenium alone in pre infection protocol

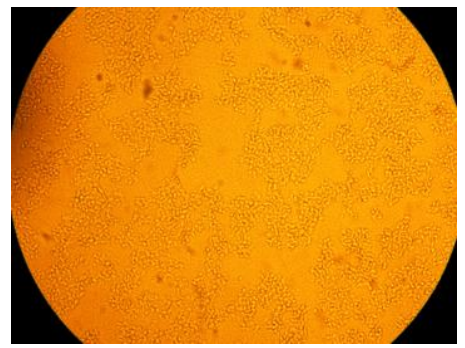

Fig. 4: $83 \%$ cytopathic effect by addition of higher con. of vitamin $\mathrm{E}$ alone in preinfection protocol.

Table (2) shows effect of selenium or / and vitamin E treatments applied with different concentrations in pre-infection protocol on $\mathrm{CPE} \%, \mathrm{GSH}$ and $\mathrm{MDA}$ levelsinMDBK cellsby BHV-1. Effects of selenium on $\mathrm{CPE} \%$ values were reached $83 \%$ and $66 \%$ in pretreatment assay, This reflected an inhibition percentage of BHV-1 by $17 \%$ and $34 \%$ in pretreatment assay at concentrations of selenium (0.01and $0.1 \mu \mathrm{M})$ respectively. GSH reached increased level in the treated control cells while the virus infected control cells (unsupplemented with antioxidants) showed the lowest level of GSH.

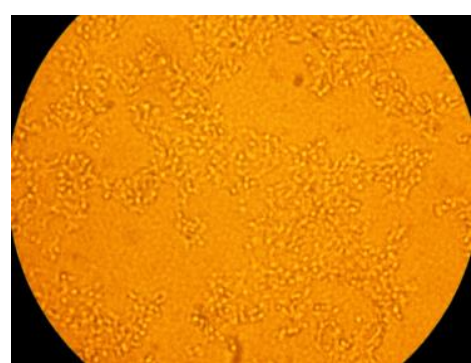

Fig. 5: Virus control with $100 \%$ cytopathic effect.

Selenium alone resulted in a concentration dependent significant $(p>0.05)$ increase in the levels of reduced glutathione at both the concentrations used a low $(0.0$ $1 \mu \mathrm{M})$ or high $(0.1 \mu \mathrm{M}$ (Table 2$)$. Our results showed that the lipid- peroxidation in MDBK cells virus control cells (un-supplemented with antioxidant), expressed as the level of MDA $(5.27 \pm 0.15 \mathrm{nmol} / \mathrm{L})$, was significantly higher $(\mathrm{p}>0.05)$ in comparison with cell control $(0.15 \pm 0.03 \mathrm{nmol} / \mathrm{L})$, as well as in comparison with the levels of MDA during selenium treatment alone. Selenium treatment alone showed significant lower concentration of MDA using the 
higher concentration $(0.1 \mu \mathrm{M})$ compared with the lower one.

Effect of vitamin Eon $\mathrm{CPE} \%, \mathrm{GSH}$, and MDAin MDBK cells by BHV-1 preinfection treatment, are shown in Table (2). CPE\% values were $100 \%$ in preinfection treatment when using concentration of $50 \mu \mathrm{M}$ vitaminE assay and reached $83 \%$ in using concentration of $100 \mu \mathrm{M}$ vitaminE. This reflected an inhibition percentage of BHV-1 by 0 and $17 \%$ in pretreatment assay at concentrations of vitamin $E$ of about 50 and $100 \mu \mathrm{M}$ respectivly. Exposure of MDBK cells to $100 \mu \mathrm{M}$ Vitamin $\mathrm{E}$ caused a significant increase in the GSH level than the lower conc. (50 $\mu \mathrm{M})$. The higher concentration $(100 \mu \mathrm{M})$ of Vitamin $\mathrm{E}$ alone showed lower level of MDA compared with the lower one.

Adding two different concentrations of selenium $(0.01$ and $0.1 \mu \mathrm{M})+$ Vitamin $\mathrm{E}(100 \mu \mathrm{M})$ showed $66 \%$ and $50 \%$ of $\mathrm{CPE} \%$ in the two different concentration of selenium respectively. This means $34 \%$ and $50 \%$ inhibition values. Higher concentration of Selenium $(0.1 \mu \mathrm{M})$ plus vitamin $\mathrm{E}(100 \mu \mathrm{M})$ treated cells showed significant $(p>0.05)$ highest level of GSH inMDBK cells and significant lowest level of MDA compared with selenium or vitamin alone groups (Table 2).

Table 2: Effect of selenium or / and vitamin E treatments applied with different concentrations in pre-infection protocol on $\mathrm{CPE} \%$, GSH and MDA on MDBK cells of BHV-1.

\begin{tabular}{|c|c|c|c|}
\hline Antioxidants in different conc. & $\begin{array}{c}\text { CPE } \\
\%\end{array}$ & $\begin{array}{c}\text { GSH } \\
(\mathrm{mg} / \mathrm{dL})\end{array}$ & $\begin{array}{c}\text { MDA } \\
(\mathrm{nmol} / \mathrm{ml})\end{array}$ \\
\hline $\operatorname{Se}(0.01 \mu \mathrm{M})$ & $83 \%$ & $0.053 \pm 0.011^{\mathrm{a}}$ & $2.37 \pm 0.68^{\mathrm{a}}$ \\
\hline $\operatorname{Se}(0.1 \mu \mathrm{M})$ & $66 \%$ & $1.93 \pm 0.35^{b}$ & $0.99 \pm 0.024^{\mathrm{d}}$ \\
\hline Vitamin $\mathrm{E}(50 \mu \mathrm{M})$ & $100 \%$ & $0.024 \pm 0.018^{\mathrm{a}}$ & $4.4 \pm 1^{\mathrm{b}}$ \\
\hline Vitamin E $(100 \mu \mathrm{M})$ & $83 \%$ & $0.059 \pm 0.029^{c}$ & $2.89 \pm 0.17^{\mathrm{a}}$ \\
\hline Se+Vit E $(0.01+100 \mu \mathrm{M})$ & $66 \%$ & $1.99 \pm 0.29^{b}$ & $0.87 \pm 0.09^{\mathrm{d}}$ \\
\hline Se+Vit E $(0.1+100 \mu \mathrm{M})$ & $50 \%$ & $2.86 \pm 0.25^{\mathrm{e}}$ & $0.57 \pm 0.012^{\mathrm{e}}$ \\
\hline Cell control & 0 & $3.5 \pm 0.64^{\mathrm{f}}$ & $0.15 \pm 0.03^{\mathrm{f}}$ \\
\hline Virus control & $100 \%$ & $0.022 \pm 0.02^{\mathrm{a}}$ & $5.27 \pm 0.15^{\mathrm{b}}$ \\
\hline
\end{tabular}

The values are means \pm S.E., CPE\% -cytopathic effect perecentage, GSH- glutathione Reduced. MDAmalondialdehyde, different letters means significantly different at $\mathrm{p}>0.05$ in the same Colum.

Table (3) showed effects of selenium or / and vitamin $\mathrm{E}$ treatment supplied with different concentrations and post infection protocol treatment assayson CPE\%, GSH and MDA in MDBK cells by bovine herpes virus -1. Results showed $100 \%$ cytopathic effect in the different groups after culture of virus. This reflected no inhibition percentage of BHV-1 by the different treatments. Treated cell control showed higher level of GSH while there was non-significant difference between different groups. Virus control cell showed higher level of MDA while there was non-significant difference between the different treated groups. 
Table 3: Effect of selenium or / and vitamin E treatments post infection on CPE\%, GSH and MDA in MDBK cells by bovine herpes virus -1 .

\begin{tabular}{lccc}
\hline \multicolumn{1}{c}{ Antioxidants in different concentrations } & CpE\% & $\begin{array}{c}\text { GSH } \\
(\mathrm{mg} / \mathrm{dL})\end{array}$ & $\begin{array}{c}\text { MDA } \\
(\mathrm{nmol} / \mathrm{ml})\end{array}$ \\
\hline Se $(0.01 \mu \mathrm{M})$ & $100 \%$ & $0.043 \pm 0.02^{\mathrm{b}}$ & $5.07 \pm 0.6^{\mathrm{b}}$ \\
\hline $\mathrm{Se}(0.1 \mu \mathrm{M})$ & $100 \%$ & $0.033 \pm 0.03^{\mathrm{b}}$ & $4.37 \pm 0.1^{\mathrm{b}}$ \\
\hline Vitamin E $(50 \mu \mathrm{M})$ & $100 \%$ & $0.083 \pm 0.02^{\mathrm{b}}$ & $5 \pm 0.53^{\mathrm{b}}$ \\
\hline Vitamin E $(100 \mu \mathrm{M})$ & $100 \%$ & $0.093 \pm 0.03^{\mathrm{b}}$ & $3.8 \pm 0.6^{\mathrm{b}}$ \\
\hline Se+Vitamin $\mathrm{E}(0.01+100 \mu \mathrm{M})$ & $100 \%$ & $0.043 \pm 0.02^{\mathrm{b}}$ & $4.9 \pm 0.52^{\mathrm{b}}$ \\
\hline Se+Vitamin $\mathrm{E}(0.1+100 \mu \mathrm{M})$ & $100 \%$ & $0.043 \pm 0.02^{\mathrm{b}}$ & $4.8 \pm 0.65^{\mathrm{b}}$ \\
\hline Control cell & 0 & $3.5 \pm 0.32^{\mathrm{a}}$ & $0.5 \pm 0.03^{\mathrm{a}}$ \\
\hline Virus cell & $100 \%$ & $0.053 \pm 0.04^{\mathrm{b}}$ & $5.27 \pm 0.8^{\mathrm{b}}$ \\
\hline
\end{tabular}

The values are means \pm S.E., CPE\% - cytopathic effect percentage, GSH- glutathione Reduced. MDAmalondialdehyde, different letters means significantly different atp>0.05 in the same Colum.

\section{DISCUSSION}

BHV-1 is able to establish a latent infection in the trigeminal or sacral ganglia (Jones, 1998). Animals with a latent BHV-1 infection may serve as a source of infection for susceptible animals if and when the virus is reactivated (Engels, and Ackermann, 1996). Oxidative stressoften accompanies viral infection, both in vivo (e.g. influenza (Oda et al., 1989 and Clerici et al., 1992) and in vitro (e.g. parainfluenza and herpes simplex type 1 (Rotilio et al., 1994 and Palmara et al., 1995). There is little understanding of how it influences virus replication. However the effect of the virus on the pro-/antioxidant balance in host cells, including virally induced inhibition of antioxidant enzymes such as glutathione peroxidase and virally induced increases in pro-oxidants such as nitric oxide; also effects of the redox state of the cell on the genetic composition of the virus as well as ROS-(reactive oxygenspices) mediated release of host cell nuclear transcription factor-kappa-B, resulting in increased viral replication (Schwarz., 1996). In the search of a common redox event affecting virus replication, it has to be taken into account that the plasma membrane represents the earliest target of virus attack and reported that oxidative stress is able to modify the activity of cell membrane ion transport systems, such as $\mathrm{Ca} 2+$ movements, $\mathrm{Na}, \mathrm{K}$-pump, and sodium, potassium, and chlorine cotransport activity (Dawson., 1996 and Dröge et al., 1994). These ion transport systems are essential for proper cellular function and viability, and their alterations may represent an early disturbance following oxidant exposure.Reduced glutathione (GSH) is the most abundant non-protein thiol in mammalian cells and the preferred substrate for several antioxidantenzymes in metabolism (glutathione peroxidase) and antioxidant defense (Meister, 1988). It plays an important role in many cellular processes, such as cell differentiation, proliferation and apoptosis ( $\mathrm{Lu}$, 1999). Malondialdehyde (MDA) is a three-carbon compound formed from peroxidized polyunsaturated fatty acids, mainly arachidonic acid. It is one of the end products of membrane lipid peroxidation. Since MDA levels are increased in various diseases with excess of oxygen free radicals, many relationships with free radical damage were observed (Ohkawa et al., 1979 and Guichardant et al., 1994).

In the current study, the viral CPE\% of BHV-1 usually appeared within 3 days after inoculation. The $\mathrm{CPE} \%$ of BHV-1 is characterized by cell rounding and ballooning, forming grape-like clusters of spherical cells gathered around a gap in the monolayer. Sometimes, giant cells with several nuclei may be observed (Figure- 1). The addition of antioxidant, selenium, with two different concentration was significantly reduced viral CPE\% asshowed intable (2). The CPE\% values were decreased $(66 \%)$ when host cells treated with the higher concentration of selenium $(0.1 \mu \mathrm{M})$ compared with the lower concentration of selenium (Fig -3 ).

In the current study, cells infected with the virus maintained in media un-supplemented with antioxidants (virus control) demonstrated a progressive decrease in glutathione reduced level and increased level of MDA. Similar results obtained by (Saguna 2008) who demonstrated that Se deficiency can be induced in Vero and SK-N-SH cells and infected with WNV (West Nile Virus). Infection of Se-deficient Vero cells leads to enhanced cell death 
by apoptosis and increased CPE\%. Exposure of tissue cells to selenium alone resulted in a significant dose dependent increase inthe level of reduced glutathione compared to control virus infected cells. This can be attributed to the enzyme GSH Px which uses GSH to reduce cellular peroxides consuming reduced glutathione in this process. (Bucker et al., 1998 and Shen et al., 2001). On the other hand, MDA declined significantly in cells exposed to selenium at a concentration of 0.1 and $0.01 \mu \mathrm{M}$. This indicates that selenium acts as a pro-oxidant at this concentrations and contributes towards building up of an oxidative environment. The inhibitory activity of selenium on viral replication was evidenced by protecting the tissue culture cells against the damaging effects of lipid peroxides and free radicals produced during viral infection Fig (3). This is evident that the higher concentration of selenium $(0.1 \mathrm{uM})$ is better than lower one (0.01) as antioxidant. Similar results with selenium has demonstrated that a deficiency in this trace element will lead to decreased glutathione concentration (Beck, 1998) and increased viral pathogenesis (Melinda., 2001 and Cai. et al., 2003).

Moreover, it is believed that low intracellular GSH levels may facilitate the course of viral infections either by increasing viral replication (De Quay et al., 1992) or activating transcription factors with consequent increased production of inflammatory cytokines, interleukin-1, and interleukin-6 (Sonia et al., 2007 and Lopez et al., 1996).

Vitamin E alone in higher concentration $(100 \mu \mathrm{M})$ decreased the $\mathrm{CPE} \%$ to $83 \%$ and increased glutathione reduced concentration and decreased malondialdehyde level while the lower concentration $(50 \mu \mathrm{M})$ showed $100 \%$ cytopathic effect after culture of virus. This reflected no inhibition percentage of BHV-1 by lower concentration of vitamin E. The same results obtained by (Peterhans 1997 and Reddy et al., 1985) with increased concentration of vitamin $\mathrm{E}$ inhibited replication of Infectious Bovine Rhinotracheitis Virus in tissue cultures. On the simplest level, vitamin $\mathrm{E}$ have protective effects on glutathione-dependent enzymes (van Haaften., 2003). Furthermore, vitamin E play a role in resistance to viral infection, Vitamin E deficiency allows a normally benign virus to cause disease (Rachel et al., 1992 and Beck et al., 1994 and). In mice, enhanced virulence of a virus resulted in myocardial injury that was prevented with adequate supply of vitamin $\mathrm{E}$ (Beck, 1994). A selenium or vitamin E deficiency leads to a change in viral phenotype, such that a nonvirulent strain of a virus becomes virulent and a virulent strain becomes more virulent (Beck, 1997, Li and Beck, 2007). Vitamin E protecting fats within the cell membrane from breaking down and prevent cellular tissue damage, in which peroxidation of lipids destroys structural integrity of the cell and causes metabolic derangements. Sung et al. (2000) suggests that, in addition to its antioxidant activity, other mechanisms might be involved in vitamin $\mathrm{E}$ beneficial effect on lowering viral titer (Fig -4).

Vitamin E and selenium have complementarybut independent roles as antioxidants in the protection of cells against the damaging effects of lipid peroxides and free radicals produced during normal metabolism (Villar et al., 2002). The cells treated with selenium and vitamin $\mathrm{E}(0.1 \mu \mathrm{M}+100 \mu \mathrm{M})$; promoted anti oxidative effect with the lower CPE\% (50\%) Fig-2 with a decrease in malondialdehyde and an increase in glutathione reduced levels. Saito et al. (2003) suggested the same results that selenium and vitamin E cooperate in the defense against oxidative stress upon cells by detoxifying and inhibiting the formation of lipid hydro peroxides.

When host cells were treated with (selenium andvitamin E.) Prior to infection, CPE\% of BHV-1 infection was reduced (Figure 2), also MDA level reduced while GSH level increased compared with post treatment infection. Thus, pre-treatment of MDBK cells with different concentration inhibited BHV-1 infectivity (table-2). However, when the antioxidants wereadded after virus penetration (posttreatment infection), the viral CPE\% of the BHV-1 was $100 \%$. This reflect need of time for syntheses of antioxidant enzymes or may be forreceptor rearrangement or translocation of preformed receptors from intracellular stores. This agree with (Chirase et al., 2004) who concluded that Pretreatment with selenium is more antioxidant than the post treatment one. This reflects selenium intake around 6 weeks prior to sampling, as GHPX is an antioxidant enzyme associated with red blood cells which are formed several weeks prior to release into circulation.In a previous study (Hayek et al., 1997) showed that old mice whose diet was supplemented with vitamin $\mathrm{E}$ for 6 weeks had significantly lower lung viral titercompared with old mice fed vitamin E following influenza infection. Also Norimasa et al. (1999) demonstrated the importance of pretreatment effect of vitamin $\mathrm{E}$ in tissue culturepolymorph nuclear leucocytes and explained that the cytoprotective effect of a-Tocopherol is attributed to its ability to act as a scavenger of highly reactive oxygen radicals, thus stabilizing membranes against lipid peroxidation and requires receptor rearrangement or translocation of preformed receptors from intracellular stores which require hours (Norimasa et al., 1999).

\section{CONCLUSION}

The higher concentration of Selenium and Vit. E (0.1 $\mu \mathrm{M}+100 \mu \mathrm{M})$ reduced the Cytopathic Effect (CPE) of BHV-1 by (50\%) and increased GSH level, decreased MDA level, in pre infection treatment assay. 


\section{REFERENCE}

ADAS (2004): Vitamin E requirements for sustainable milk production. DEFRA Final Project Report LS3507.

Afshar, A and Eaglesome, M.D. (1990): Viruses associated with bovine semen. Vet. Bull., v. 60, p. 93-109.

Allison, R.D. and Laven, R.A. (2000): Effect of vitamin $E$ supplementation on the health and fertility of dairy cows: a review. Veterinary Record. British Veterinary Association, London, UK. 147: 25, 703-708.

Beck, M.A.; Kolbeck, P.C.; Rohr, L.H.; Shi, Q.; Morris, V.C. and Levander, O.A. (1994): Vitamin E deficiency intensifies the myocardial injury of coxsackievirus B3 infection in mice. J. Nutr. 124: 345-358.

Beck, M.A.; Shi, Q.; Morris, V.C. and Levander, O.A. (1995): Rapid genomic evolution of a nonvirulent coxsackievirus B3 in seleniumdeficient mice results in selection of identical virulent isolates. Nat. Med. 1: 433-436.

Beck, M.A. (1997): Rapid genomic evolution of a non-virulent coxsackievirus B3 in seleniumdeficient mice. Biomed. Environ. Sci. 10: 307315.

Beck, M.A. (1998): The influence of antioxidant nutrients on viral infection. Nutr. Rev., 127, S140-S146.

Beutier, E.; Duron, O. and Kelly, MB. (1963): Colorimetric method for determination of glutathione reduced. J., Lab Clin. Med., 61, 832.

Bradley, R.; Anderson, P.H. Wilesmith, J.W. (1986): Changing patterns of nutritional myodegeneration (white muscle disease) in cattle and sheep in the period 1975-1985 in Great Britain. Proceedings of the 6th International Conference on Production Disease in Farm Animals, Belfast. Pp. 248-251.

Biswas, S.; Bandyopadhyay, S.; Dimri, U. and Patra, PH. (2013): Bovine herpesvirus-1 (BHV-1) $i$ a re-emerging concern in livestock: a revisit to its biology, epidemiology, diagnosis, and prophylaxis. Vet Quarterly, 33: 68-81.

Bucker, R.D.; Bucker, C.C. and Rao, R. (1998): Selenium deficiency in tissue culture, Pediatr Gastroenterol Nutr 1998 Oct; 27(4): 387-92.

Cai, J.; Chen, Y.; Seth, S.; Furukawa, S.; Compans, R.W.; Jones, D.P. (2003): Inhibition of influenza infection by glutathione. Free Radical. Biol. Med. 2003, 34, 928-936.

Cebra, C.K.; Heidel, J.R.; Crisman, R.O. and Stang, B.V. (2003): The relationship between endogenous cortisol, blood micronutrients, and neutrophil function in postparturient Holstein cows. Journal of Veterinary Internal Medicine 17 [6] 902-907.
Clerici, C.; Friedlander, G. and Amici, C. (1992): Am. J. Physiol. 262, L542-L548.

Chirase, NK.; Greene, LW.; Purdy, CW.; Loan, $R W$.; Auvermann, BW.; Parker, DB.; Walborg, EF.; Stevenson, DE.; Xu, $Y$. and Klaunig, JE. (2004): Effect of transport stress on respiratory disease, serum antioxidant status, and serum concentrations of lipid peroxidation biomarkers in beef cattle. Am. J. Vet. Res. 65: 860-864.

Chowdhury, S. (2010): Bovine herpesvirus type 1 (BHV-1) is an important cofactor in the bovine respiratory disease complex. Vet. Clin. North Am Food AnimPract, 26: 303-321. PubMed Abstract | Publisher Full T

Dawson, T.M. (1996): Free radicals and neuronal cell death. Cell Death Differentiation 3: 71-78.

De Quay, B.; Maliverni, R. and Lauterburg, B.H. (1992): Glutathione depletion in HIV-infected patients: Role of cysteine deficiency and effect of oral N-acetylcysteine. Aids; 6, 815-819.

Dröge, W.; Eck, H.P. and Mihm, S. (1994): Oxidantantioxidant status in human immunodeficiency virus infection. In: Oxygen Radicals in Biological Systems (Packer, L., ed.), pp. 594601. Academic Press, San Diego, CA.

Engels, M. and Ackermann, M. (1996): Pathogenesis of ruminant herpes virus infections. Vet. Microbiol., 53: 3-15. doi. 10. 1016 /so378. 1135 (96): 01230-8.

Hayek, M.G.; Taylor, S.F. and Bender, B.S. (1997): Vitamin E supplementation decreases lung virus titers in mice infected with influenza. $\mathbf{J}$. Infect Dis.; 176: 273-276.

Guichardant, M.; Vallete -Talbil.; Cavadini, C.; Rozier, G. and Berger, M. (1994): Malondialdehyde measurement in urine. J. Chromatogr B Biomed Appl 655: 112-116.

Jones, C. (1998): Alphaherpes virus latency: its role in disease and survival of the virus in nature. Adv virus Res. 51: 81-133.

Kommisrud, E.; Osteras, O. and Vatn, T. (2005): Blood selenium associated with health and fertility in Norwegian dairy herds. ActaVeterinaria Scandinavica 46 [4] 229-240.

LeBlanc, S.J.; Duffield, T.F.; Leslie, K.E.; Bateman, K.G.; TenHag, J.; Walton, J.S. and Johnson, W.H. (2002): The effect of prepartum injection of vitamin $\mathrm{E}$ on health in transition dairy cows. Journal of Dairy Science 85 [6] 1416-1426.

Li, W. and Beck, MA. (2007): Selenium deficiency induced an altered immune response and increased survival following influenza A/Puerto Rico/8/34 infection. Exp Biol. Med. (Maywood); 232: 412-419.

Lopez Galera, R.M.; Juarez Gimenez, J.C.; Montoro Ronsano, J.B.; Segura Cardona, R.M.; Arbos Via, M.A.; Altisent Roca, C. and Tusell Puigbert, J.M. (1996): Glutathione and 
cysteine in HIV-infected hemophiliacs. Clin. Chim. Acta, 254, 63-72.

Lu, S.C. (1999): Regulation of hepatic glutathione synthesis: current concepts and controversies. FASEB J., 13, 1169-1183. 3.

Meister, A. (1988): Glutathione metabolism and its selective modification. J. Biol. Chem, 263, 17205-17208.

Melinda, A.B. (2001): Selenium, Kluwer Academic publisher, pp, 235-245.

Mikko Sillanpaa, HakanJansson., (1992): Status of Cadmium, Lead, Cobalt and Selenium in Soils and Plants of Thirty Countries, Food and Agriculture Org., Jan 1, 195 pages.

Moron, Ms.; Depierre, JW. and Mannervik, B. (1979): Levels of glutathione, glutathione reductase and glutathione $-\mathrm{s}-$ transeferase activities in rat lung and liver. Biochim Biophys Acta., 582: 67-78.

Nelson, H.; Shi, KQ.; Van Dael, P. and Schiffrin, EJ. (2001): Host nutritional selenium status as a driving force for influ-enza virus mutations. FASEB J. 15: 1846-1848. Pub Med.

Norimasa Yoshida; Toshikazu Yoshikawa; Hiroki Manabe; Yoshimitsu Terasawa; Motoharu Kondo; Noriko Noguchi and EtsuoNiki, (1999): Vitamin E protects against polymorphonuclear leukocyte-dependent adhesion to endothelial cells Japan Journal of Leukocyte Biology Volume 65, June 757.

Oda, T.; Akaike, T.; Hamamoto, T.; Suzuki, F.; Hirano, T. and Maeda, H. (1989): Science 244, 974-976.

Ohkawa, H.; Ohishi, N. and Yagi, K. (1979): Assay for lipid peroxides in animal tissues by thiobarbituric acid reaction. Anal Biochem 95: 351-358.

Palamara, A.T.; Perno, C.F.; Ciriolo, M.R.; Dini, L.; Balestra, E.; D' Agostino, C.; Di Francesco, P.; Favalli, C.; Rotilio, G. and Garaci, E. (1995): Antiviral Res. 27, 237-253. Cross Ref. Medline Google Scholar.

Peterhans, E. (1997): Oxidants and antioxidants in viral diseases: Disease mechanisms and metabolic regulation. J. Nutr., 127, S962S965.

Rachel, I.M.; van Haaften, Guido, R.M.M.; Haenen, T.; Chris, T.A. Evelo, and AaltBast, (1992): Effect of Vitamin E on Glutathione-Dependent Enzymes J. Gen. Virol. 73, 39-46.

Rayman, MP. (2000): The importance of selenium to human health. Lancet.: 356: 233-41.

Reddy, P.G.; Morrill, J.L.; Minocha, H.C. and Frey, R.A. (1985): Effect of serum from Vitamin Esupplemented calves on Infectious Bovine Rhinotracheitis Virus replication. Conference paper.

Reed, L.J. and Muench, H. (1938): A simple method for estimating fifty percent end points. Am. J. Hyg., 27: 393-497.
Rotilio, G.; Knoepfel, L.; Steinkuhler, C.; Palamara, A.; Ciriolo, M.R. and Garaci, E. (1994): Oxidative Stress, Cell Activation, and Viral Infection (Pasquier C., Olivier R.Y., Auclair C., Packer L., eds), pp. 143-153, Birkhauser Verlag, Berlin Google Scholar.

Saguna Verma, 1.; Yeung, Lo, 1; Moti Chapagain; Stephanie Lum; Mukesh Kumar; Ulziijargal Gurjav; Haiyan Luo; Austin Nakatsuka, and Vivek R. Nerurkar (2008): West Nile virus infection modulates human brain microvascular endothelial cells tight junction proteins and cell adhesion molecules: Transmigration across the in vitro blood-brain barrier. Virology. 2009 Mar 15; 385(2): 425-433.

Satoh, K. (1978): Calorimetric determination of glutathione reduced. Clinica Chimica Acta, 90, 37.

Saito, Y.; Yoshida, Y.; Akazawa, T.; Takahashi, K. and Niki, E. (2003): Cell death caused by selenium deficiency and protective effect of antioxidants. J. Biol. Chem., 278, 3942839434.

Shen, J.; TT, SS.; Schrieber, L. and King, NJ. (2001): Early E-selectin, VCAM-1, ICAM-1, and late major histocompatibility complex antigen induction on human endothelial cells by flavivirus and comodulation of adhesion molecule expression by immune cytokines. J Virol.; 71(12): 9323-32.

Schwarz, K.B. (1996): Oxidative stress during viral infection: a review. Free Radic Biol Med. 1996; 21(5): 641-9.

Sivertsen, T.; Overnes, G.; Osteras, O.; Nymoen, U. and Lunder, T. (2005): Plasma vitamin E and blood selenium concentrations in Norwegian dairy cows: Regional differences and relations to feeding and health. Acta Veterinaria Scandinavica 46 [4] 177-191. Moron et al., 1979.

Smits, C.B.; Van Maanen, R.D.; Glas, R.D.; De Gee, A.L.; Dijkstrab, T.; Van Oirschot, J.T. and Rijisewijk, F.A. (2000): Comparison of three polymerase chain reaction methods for routine detection of bovine herpesvirus 1 DNA in fresh bull semen. J. Virol. Methods, 85, 65-73.

Snedecor, W. and Cochran, W.G. (1987): Statistical Methods. Oxford and IBM Calcutta, pp 593. Subramanian, S. and M. Rathinam, 1984.

Sonia, S. and Mohinder, P.B. (2007): Co-operative effect of glutathione depletion and selenium induced oxidative stress on API and NFkB expression in testicular cells in vitro: insights to regulation of spermatogenesis. Biol. Res. 40: 307-317, 2007.

Sung, N.H.; Mohsen, M.; José, V.C.; Dayong, W.; Bradley, S.B.; Donald, E.; Smith, A. and Guohua, C. D (2000): Effect of Long-term Dietary Antioxidant Supplementation on 
Influenza Virus Infection. Gerontology Journal series A, 27.

Taylor, E.W.; Nadimpalli, R.G.; Ramanthan, C.S. (1997): Genomic structures of viral agents in relation to the biosynthesis of selenoproteins. Biol Trace elements Res. 56., 63-91. 47.

Taylor, E.W.; Ramanathan, C.S.; Jallui, R.K. and Nadimpalli, R.G. (1994): Abasis for new apptoaches to the chemotherapy of AIDS. Novel genes in HIV-1 potentially encode selenoproteins expressed by ribosomal frameshifting and termination suppression. J. Medchem. 37: 2637-2654.

Van der, Oirschot, J.T. (1995): Bovine herpes virus 1 in semsn of bulls and the risk of transmission, a brief review. Vet. Q., 17(1), 29-33.

VanHaaften, R.I.; Haenen, G.R.; Evelo, C.T.; Bast, A. (2003): Effect of vitamin $E$ on glutathionedependent enzymes. Drug Metabolism Reviews. Vol. 35, Nos. 2 \& 3, pp. 215-253, 2003.

Villar, D.; Arthur, J.R.; Gonzalez, J.M.; Pallares, F.J. and Carson, T.L. (2002): Selenium status in cattle: interpretation of laboratory resultsBovine Practitioner. American Association of Bovine Practitioners, Stillwater, USA: $36: 1,73-80$.

\section{تاثثير اضافة السيلنيوم و/ او فيتامين هـ على الخلايا المصابة بفيروس هربس الابقارــ فى خلايا الزرع النسيجي

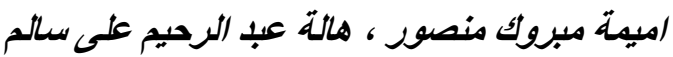

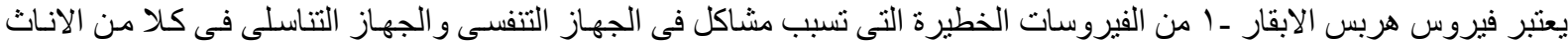

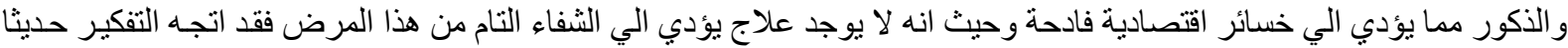

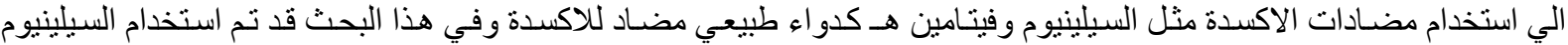

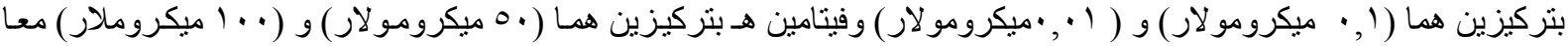

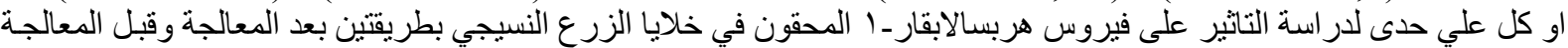

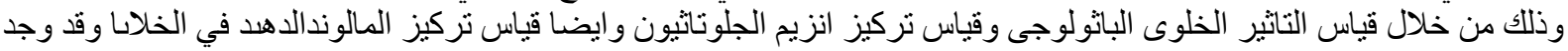

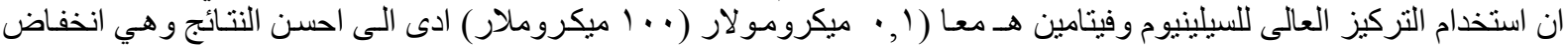

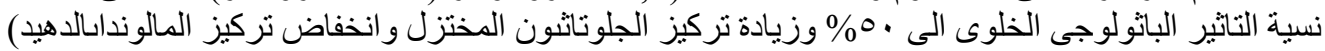

